\title{
Café Imports Case Study - Building Sustainable Competitive Advantage Through Principled Entrepreneurship
}

\author{
Jay Ebben \\ University of St. Thomas \\ Alec Johnson \\ University of St. Thomas
}

This case study was written to illustrate how a for-profit company can build sustainable competitive advantages via principled entrepreneurship. The case follows a recent college graduate's journey at a mission-driven coffee importer and asks students to analyze how he developed strategic initiatives that align with the company's core values. The case leaves students with three main perspectives: 1) Pursuit of the common good is not limited to not-for-profit firms; 2) Entrepreneurial firms do not need to sacrifice their core values in order to compete; and 3) Core values should be considered in commonly-used analysis frameworks such as Porter's Five Forces.

Keywords: principled entrepreneurship, sustainable entrepreneurship, values-driven entrepreneurship, business for the common good

\section{INTRODUCTION}

On a plane high above the Pacific Ocean, Noah Namowicz reflected on his journey the past five years with Café Imports. Largely under the direction of the now-thirty-year-old, the company had set out to do something no other importer of green coffee beans had ever been able to do: become known worldwide as the premier importer of high-quality coffee beans. Noah had been responsible for creating a brand around Café Imports, developing relationships with growers in mainly third-world countries, and getting the word out to the coffee roasters who bought beans. Through this process, Noah also saw an opportunity to make Café Imports, which had always considered itself a mission-driven company, a leader in improving the lives of coffee suppliers, and he had implemented several programs that did just that. And now, after personally setting up the company's first international offices in Berlin and Melbourne, he had received an offer to become the first employee-shareholder of the company.

Yet even with all of its successes, Noah felt like there was so much more the company could do, and so much more it would need to do to stay ahead of its competition. He leaned his seat back and turned his focus to what the right moves for himself and the company might be moving forward. 


\section{BACKGROUND}

Noah Namowicz grew up in a suburb of Milwaukee in a family of entrepreneurs. His grandfather had started his career by loading up a truck full of cheese in Arcadia, Wisconsin and making a five-hour drive to Chicago every day to sell it, and later owned an egg-cracking plant. His parents started a staffing business, which they grew and sold. Noah spent a great deal of time helping out in these businesses during his childhood.

After graduating from high school, Noah decided he wanted to move out west, so he enrolled at Colorado University in Boulder. "I spent all of my time partying, and none of my time going to class," he recalled. "Needless to say, I didn't last long." With nearly all failing grades his freshman year, he was told by his parents they weren't going to continue to pay for his education.

Noah realized he needed to clean up his act if he was going to get anywhere in life. Rather than going back to Milwaukee, he moved to St. Paul where he didn't know anyone to get a fresh start. "I needed to sober up, so I could get to work," he said.

His plan was to take a few classes at St. Paul College and then enter the entrepreneurship program at the University of St. Thomas as a full-time undergrad. But the first time he applied, he was rejected because of his grades at Colorado. So, he applied again.... and he was rejected again. So, he applied a third time... and he was rejected again. Finally, on his fourth try, at twenty-one years old, he was accepted.

"I was determined I was going to get into St. Thomas," he said. "I had heard great things about the entrepreneurship program. Plus, getting rejected pissed me off. I was going to get accepted, and I was going to get straight A's once I did just to show them they made a mistake."

Not only did Noah get straight A's at St. Thomas, he also started playing around with business ideas. One of those was a shared office concept he called "Megan Friday's." His vision was to develop a collaborative co-working space geared toward creative professionals, in which they could simply pay for a desk and have access to the amenities a larger office would provide. The idea was that complementary skill sets would exist in a group of like-minded individuals and they would receive value from meeting and working with others in the shared office space (like a writer and graphic designer and copy editor, for example).

Noah introduced himself to a guest speaker in one of his entrepreneurship classes and told him about Megan Friday's. The speaker, Erik, had heard about similar concepts on the west coast and was intrigued with opening one here. Erik had a real estate background and many connections in the creative world, and he and his business partner began speaking with Noah in earnest about this concept. Over a six-month period, the three of them investigated potential locations and laid out the financing that would be required to develop them.

In the end, Erik and his partner decided the timing was not right for them to take on this project. Noah also came to that conclusion, but only after winning his entrepreneurship capstone business plan competition with the concept. "I still pursued it a bit after that and I just realized that I wasn't ready to do it by myself," Noah said. "So, Megan Friday's ended up coming to fruition through another company called CoCo, which essentially has a very similar model. Different guys started it and they're doing really well. So, I think it just provided to me that my intuition was right, and more than anything kind of instilled that I should follow my gut."

\section{CAFÉ IMPORTS}

In the meantime, Noah had decided he should get a "figure-it-out" job: a job where he could earn some money and get some experience while finding a new partner for Megan Friday's and working on how and where to open that business.

While at St. Thomas, Noah had taken up an interest in coffee. He spent a lot of time studying at a new specialty coffee shop called Kopplin's, which was halfway between his house and campus. "I would go there and they were doing just crazy stuff with coffee, things I never even thought about: brewing different 
coffees different ways and highlighting coffees, telling the stories about them. And it all seemed very exotic and very sexy and it was like, 'Oh this is kind of cool."'

Nearing graduation in 2009, Noah heard about a local importer of coffee from a family friend who worked there. "He had basically said that he had this job where he got to taste coffees from around the world and travel and do all kinds of fun stuff," Noah recalled. "So, he was one of the people that I sent my resume to when I was about to graduate and it just so happened that they were really short staffed. At that time, there were only five or six employees and so I was the seventh. So, they hired me, when I think I had like three months left of school, I got a formal offer and then right after school came here."

During his interview, Noah found himself impressed with the founder of Café Imports, Andrew Miller, and how he talked about company values (see Exhibit 1). For instance, Andrew explained to Noah the importance of developing long-term relationships with coffee farmers rather than just showing up to buy their beans. Andrew believed that helping farmers cultivate higher-quality coffee beans and providing them a way to get those beans to consumers was also a way to empower them to live better lives. "We don't just want to buy coffee....we want to buy coffee better," he told Noah.

Andrew also told Noah that part of buying coffee better was making a commitment to sustainability, especially because all of the activities involved in importing coffee tend to leave a heavy carbon footprint. With this in mind, Andrew had partnered with Trees for the Future in 2005 to perform a carbon audit of the company's business. Based on that audit, he purchased 80,000 trees to be planted in Central America to offset Café Imports' carbon emissions, which would keep the company carbon neutral through 2016. Andrew also talked about what they do in their office to be environmentally responsible, like rewarding employees who bike or carpool to work and maintaining a compost bin for organic materials from the kitchen.

In turn, Andrew was impressed with Noah and the fact that he came into the interview prepared with ideas that the company could pursue. "I had ideas about roasting coffee and private labeling it for ad agencies or something like that," Noah recalled. "It didn't fit the model, because we don't sell roasted coffee. But, I think that they appreciated the thought, the ingenuity, or just the hunger that was behind that, like we could do this, we could do this, we could do this. I think they wanted to bring someone in that had that fire."

\section{THE COFFEE INDUSTRY IN 2015}

The vast majority of coffee in the world was grown in developing countries and consumed in wealthier nations. The U.S. was the largest importer of coffee, with the retail value of coffee sold in the U.S. estimated to be around $\$ 30$ billion in 2012 (Specialty Coffee Association, 2016). Per capita consumption of coffee in the U.S. was steady from the early 2000's, ranging between 9.1 and 10.3 pounds per person from 2000 to 2015 (see Exhibit 2). Growth in consumption per capita was expected to be $0.9 \%$ annually through 2020 (IBIS World, 2016).

The industry was generally made up of three main players in the supply chain:

- Growers: There were approximately 25 million coffee growers in the world (Mello, 2012). The largest coffee-growing country by far was Brazil, which accounted for approximately $30 \%$ of world production (see Exhibit 3). Growers were generally poorer farmers, who relied solely on proceeds from the coffee harvests for their income each year. These proceeds were greatly impacted by fluctuations in world coffee prices.

- Importers: Coffee importers set up relationships with growers, often financing the growers through the growing season until harvest. Importers would buy bulk beans from the growers that they in turn sold to coffee roasters or to coffee shops that roast their own beans. Some importers also had their own roasting operations, such as Starbucks, which imported, roasted, and retailed the beans it sourced from growers. Importers maintained small margins and generally invested in futures to offset the risk of declines in coffee prices. The vast majority of import volume came through large importers such as Olam, Royal Coffee, Volcafe, 
Interamerican, and Atlantic. These importers were generally owned by multinational companies and purchased high-volume, less-traceable coffees.

- Roasters: Roasters bought green beans from importers, which they then roasted and sold. The flavor depended both on the bean and roasting technique, while freshness was dependent on when the coffee was ground (which was why coffee connoisseurs waited to grind their beans just before making coffee). Larger roasters, like Folgers or Green Mountain Coffee, branded their roasted beans and sold them to grocery stores, or they white-labeled their roasted beans for coffee shops that did not do their own roasting. Roasters received the highest margins in the industry.

Consumer tastes within coffee were trending toward specialty coffees (see Exhibit 4), single-serve coffees (such as "k-cups"), and responsibly-grown coffee (such as fair trade and shade grown coffee). Specialty coffee made up $37 \%$ of the volume of coffee sold in 2012 , but $50 \%$ of the total sales in dollars (Specialty Coffee Association, 2016). In 2013, 13\% of the U.S. population drank coffee made from singleserve coffee makers (Fernau, 2013). Consumer tastes outside of coffee that were impacting the market included the rising popularity of energy drinks and tea among the younger age groups (see Exhibit 5).

\section{THE REBRANDING EFFORT}

By 2011, Noah had worked his way up to sales representative and then director of marketing. That year, Café Imports embarked on a rebranding strategy. Up until that time, importers of coffee beans were essentially commodity dealers: there was little to no discernable difference between them in the eyes of their customers. Noah and his team asked the question, "What if we became known as the premier importer of high-quality coffee beans?" The company had already been importing high-quality beans, and branding around this might allow them to do two things: 1) the ability to garner higher margins in an extremely lowmargin business, and 2) create awareness of the important role coffee bean growers play in the supply chain.

"Before I came on, Café Imports was sourcing these higher-end, more traceable lots of coffee, but we weren't positioned like that at all in the industry," Noah said. "The owners were making strides in buying better coffees, but it wasn't being translated in a way that the larger coffee community understood. So, we wanted to transition ourselves into being kind of a household name for coffee roasters: we wanted them to know that if they wanted to get really high-quality coffee, they should get it from us."

At the time, no coffee importers were positioned in this niche, so there was a real opportunity for Café Imports if they could pull it off. "It's really challenging because you can make a lot of money just flipping containers and doing volume coffees," Noah said. "But the flip side of that is there's no way to increase the quality of life for the producers that you're working with if you're just buying and selling it as a commodity."

Noah began the rebranding effort by focusing even more on getting the highest-quality supply possible. As a start, the company further developed its incentive system in which coffee farmers would get paid based on the quality of the coffee. If farmers produced coffees that scored about 86 points, they would receive a premium.

In 2012, Noah became the Director of International Sales and started to build Café Imports' image with customers in global markets. In addition to rebranding the logo and website (which had been focused on the sustainability aspect rather than high-quality), he began focusing on how roasters communicate quality to their customers. One issue that coffee shops face is that the average coffee-drinker has a difficult time tasting quality differences. Noah and his team began creating stories of the coffee farmers that shops could display for their customers.

"The biggest accomplishment I think that we've done in this rebranding is we've created a platform, which is called "The Beanology," Noah said. "Essentially, it's a framework for us to be able to input the farm information, so when somebody buys a coffee, we say, 'Oh yeah, and here's the PDF.' We email them the link, which has photos of the producer, a little bit of their story, videos, and all of the skeletal information like variety, altitude, how it's processed... It's like why wouldn't I buy from Café Imports if they make it this easy? So, most customers are taking our stuff, repackaging it under their own branding and then 
transmitting that to their customers. It's gotten to the point where if the coffee doesn't have that information, they won't buy it." This effort also began highlighting coffee growers as human beings with a skilled craft.

A second effort was placed in the growing barista competition space. In these competitions, baristas would tout the source of their coffee, becoming an advertiser in a sense. At the time, none of the sponsors were coffee importers, and Noah saw an opportunity to become the competition coffee brand. Noah organized a sponsorship in which the winning barista would travel to a coffee-producing country with Café Imports to meet growers and see how coffee was produced. This was appealing to baristas because most had not had an opportunity to do this. And it was appealing to Café Imports, because it got its brand in front of the top baristas.

"So, suddenly we had a brand, and when people checked it out they saw this beautiful website with photos and videos, and we became the place. That's when baristas who were competing started coming to us to help them find a competition coffee. Then that demand, because the baristas work for our customers, trickled down into the ownership of those companies and they said, 'Oh yeah, we should look at Café Imports."”

A third piece was the "Variety Tree," which Noah's team developed to comprehensively map out the hundreds of varieties of coffee (see Exhibit 6). Noah sent the variety tree poster to every roaster in the country. "Every roaster has that poster up in their roasting space. It's like us getting free real estate in roaster spaces, because for being such an established industry, coffee has such a lack of scientific research behind it and whenever anyone comes out with something, people are just hungry to soak up the information."

The company also added an educational space to its headquarters, which it named the Minneapolis Coffee Mill (see Exhibit 7). According to Noah, it was designed to give Café Imports a space for people to "come and just play with coffee and get to know coffee" and not as a money-making venture. "We were starting to see an explosion of small roasters popping up all over the country," he said. "Our education focus was meant to help capture those new people that were trying to figure out how to learn about roasting coffee." They developed three-day courses on roasting, barista technique, and cupping that were offered quarterly, and roasters would come in from all over the country to take them.

Because of their success in rebranding, Café Imports began to see a movement in the competition toward specialty coffee. Several of the large importers opened specialty coffee branches or repositioned themselves as high-end coffee importers altogether; for example, Volcafe introduced "Volcafe Specialty Coffee". Additionally, a few very small importers emerged that only imported high-end coffees, such as Atlas Coffee, Coffee Shrub, Red Fox, and Nordic.

\section{DOING GOOD FOR COFFEE SUPPLIERS}

While building relationships with their coffee suppliers, Noah and his team began to recognize ways they could create opportunities for these individuals and their families, and that, in general, what was good for their suppliers was good for Café Imports. The company began to implement training programs to help coffee growers think about their beans from a "sale-ability" perspective, and on growing, drying, and other techniques that would result in higher-quality beans. In addition, together with growers and others in the coffee origin supply chain, Noah and his team created programs in which suppliers would have the opportunity to make significant premiums on their coffee.

\section{Best Cup Competition}

One such program was the Best Cup Competition, which Café Imports developed alongside its Columbian export partner, Banexport. This annual event focused on a small, coffee-growing region of Columbia and included a multi-day cupping competition and live auction. Farmers would submit their lots of top-quality coffee and Café Imports' buyers would go to the auctions and taste and evaluate the submissions. The coffees that rated the highest would receive significant premiums, sometimes giving a farmer the equivalent of an entire year's wages from a single lot of coffee.

"We were able to incorporate that quality piece into the social aspect of paying people fairly. That has created a healthy sense of competition with the newest producers to do things right, because they get paid 
for it. So, we found that it was the best way for us to accomplish both getting the best coffees possible and also increasing the quality of life for the producer partners that we have."

\section{Women Coffee Producers Program}

In addition to financial constraints, another major issue Café Imports observed in coffee-growing communities was that of gender inequality. While seventy-percent of the labor on coffee farms was performed by women, women were vastly under-represented in terms of land ownership and coffee association membership - this number is less than twenty-percent in most countries, and as low as fivepercent in some (Café Imports, 2018). Additionally, in many of these countries, land ownership does not get passed on to a wife after her husband passes away or emigrates from home.

To help raise awareness around these issues and empower women coffee farmers, Café Imports initiated its Women Coffee Producers Program. For the program, Café Imports partnered with groups (or cooperatives) of women coffee farmers, like the Asociación de Mujeres Productoras Agropecurarias del Cauca in Columbia. The company pays a premium for coffees sourced through this program, and the cooperative gets to decide what to do with the extra income. For instance, one cooperative in Mexico has used its premium to fund cervical cancer screening for women in the community.

\section{Microlot Programs}

On the sales side, the company began developing creative ways to connect coffee roasters in the U.S., Europe, and Australia with farmers in the countries of origin. One of these efforts was through the sale of what they labeled "Microlots", or small lots of premium coffees. Many of these coffees came from the Best Cup competitions, but some were also sourced from the Women Coffee Producers Program and other events the company organized. Coffees selected for microlots commanded a premium for farmers.

Microlot coffees that rated above 90 were sold in the Café Imports Aces program (the name coming from being dealt double aces in poker, alluding to the exquisite quality of these coffee beans). Aces lots were sold in small 20 kilogram bags, as opposed to the typical 150-pound bags, on a first-come, first-served basis. These bags showcased specific details on where the lot originated, including the name of the farmer and aspects such as altitude grown and production methods (see Exhibit 8).

\section{Coffee Send-Back Program}

A fourth effort that was initiated was the Coffee Send-Back program, in which roasters could send farmers a bag of their beans after they had been roasted. The concept here was twofold: 1) Coffee farmers generally had no idea how their coffee beans tasted in a cup and this was a way for them to appreciate the quality they had produced, and 2) It was a way for roasters to thank farmers and begin building relationships with them.

\section{COMPANY GROWTH}

The strategies Noah and his team used to build country-of-origin relationships and empower coffee farmers, along with their rebranding effort, resulted in significant growth for the company. Not only did Café Imports begin selling significantly more of its high-quality coffees, but the quality image began to impact sales of their other coffees as well. Roasters that were attracted to Café Imports because of their lower-volume, high-quality coffee also began sourcing their higher-volume mid-tier coffees from Café Imports.

By 2015, Café Imports had grown from 8 to 37 employees, and had achieved approximately $20 \%$ growth in sales annually for the previous four years. The company began attracting barista competitors and former roasters as new employees, who were drawn to the company's image and culture, adding to the company's expertise. The company even hired an agronomy (the science of soil management and crop production) student from the University of Minnesota and created a team dedicated to developing ultraspecific cupping recipes (including attributes such as water composition down to the drop) so that exact flavors could be replicated around the world. 
"The culture kind of went from being just fine, to now being a very attractive, hip, cool place to work in the industry," Noah said. "And you can see with the coffee bar and stuff that we built out, we tried to build a space that spoke to that, because that's the image that we're putting out there and we need to have some substance behind it. So, I think that our staff is young and energetic and it's very much in line with the brand image that we put out there."

To reinforce their expert image and capability, the company spent significant resources on training new employees. Employees needed to be knowledgeable on aspects such as buying green coffee (which is challenging because of fluctuating price points), quality control and cupping (learning to taste, evaluate, and score coffees, which is a developed skill), and sales (which entails mentorships with senior sales staff and customer service), just to name a few.

"We sort of have the mindset here that we want everyone to be brought up through our system," Noah said. I think it really takes about two years to get up to the point where you can be confident in backing up the fact that we're saying that we're experts. And that's why we don't let introductory customer service people talk to customers on the phone about coffees. We want them to process the orders, but we want the customers to talk to somebody that can be the expert for them."

\section{New Avenues for Growth}

As a means for promoting an entrepreneurial culture, Noah had implemented a quarterly company-wide "hotwash" event, in which any employee in the company could pitch a new idea. The concept came from the Practicing Entrepreneurs group that Noah was part of at the University of St. Thomas, an informal group of students who regularly pitched business ideas to each other and received feedback. Noah thought this would be a fun way to engage employees and to encourage them to be thinking about ways to make the company better. "It's amazing how many really good ideas come up at these events... ideas that we would never otherwise hear about," he remarked.

One of the ideas that had recently come up at the event was to develop a new brand that would be sold in smaller bags to micro-roasters. The thought was that if these roasters did not have to commit to 150 pound bags of coffee, it would allow them to experiment more with different styles of beans which they would find appealing. In turn, Café Imports could charge more per pound selling in smaller bags. While Noah loved this as a concept, he was not sure there would be enough demand from micro roasters to be worth dedicating the resources that would be required to do it right. He also was not sure whether this might cannibalize their existing sales to micro roasters, and he was concerned that they might end up buying less coffee overall if they had this option.

Additionally, Noah was considering whether to hire a full-time Creative Director. He knew the company had only scratched the surface when it came to revitalizing its website, creating content for social media, and developing more overall consistency in brand look and messaging, and he believed a person dedicated to these tasks would be a major asset. He also thought he knew the perfect person to fill the position: Andy Reiland, a good friend of his from high school who had also graduated from the entrepreneurship program at St. Thomas (and who happened to be between jobs). At the same time, hiring a salaried person would add a significant burden to the budget, and Noah was hesitant to reach out to Andy until he was certain he wanted to head down this path.

\section{WHAT NEXT?}

On his flight, Noah thought about the offer he had on the table to become a shareholder. Noah had made it clear to Andrew early on that he was interested in being more than just an employee, and he promised he would work toward making this happen. Now that Noah had proved his value to the company, Andrew had made good on his promise.

But in becoming an owner, Noah would become that much more committed to Café Imports, and he wondered what was in store for the company over the next few years. It wasn't realistic to believe the coffee market would grow significantly, and it wasn't a given that recent growing interest in specialty coffees and the micro-roaster movement would continue either. Additionally, competitors were rapidly copying many 
of the company's initiatives, such as setting up auction-style competitions for farmers in countries and regions where Café Imports had not yet set up a Best Cup event. Noah found himself spending a lot of time these days contemplating how to stay ahead of the competition, and he wondered whether hiring Andy and moving forward with the new "small-bag" initiative were the right directions for the company.

Regardless, Noah felt surprisingly at ease. He knew he had found his calling, and he looked forward to whatever his future at Café Imports would bring.

\section{FIGURE 1 \\ CAFÉ IMPORTS MISSION AND VALUES}

\section{$\underline{\text { Our Mission }}$}

- To bring to the global market the highest-quality green coffees in the world by sourcing, developing, and innovating at origin, while empowering farmers with price, traceability, and long-term partnerships.

- To consistently exceed customers' expectations of the specialty-coffee buying experience with exemplary service.

- To spread our passion for great coffee through education and example from the farm to the roaster, retailer, and ultimately to the cup.

\section{Our Values}

To be engaged and foster creativity in a dynamic industry through a focus on exploring every facet of coffee. To be honest, ethical, and respectful, and remain teachable in the ever-changing world of coffee.

- INCREASE the quality of life for those involved - from the tree to the cup - through the commerce of coffee.

- DECREASE our negative impact on the earth through responsible and proactive business practices that emphasize environmental sustainability.

- SHARE our passion for great coffee through education and example.

Café Imports (2016a)

\section{FIGURE 2 \\ U.S. COFFEE CONSUMPTION PER CAPITA}

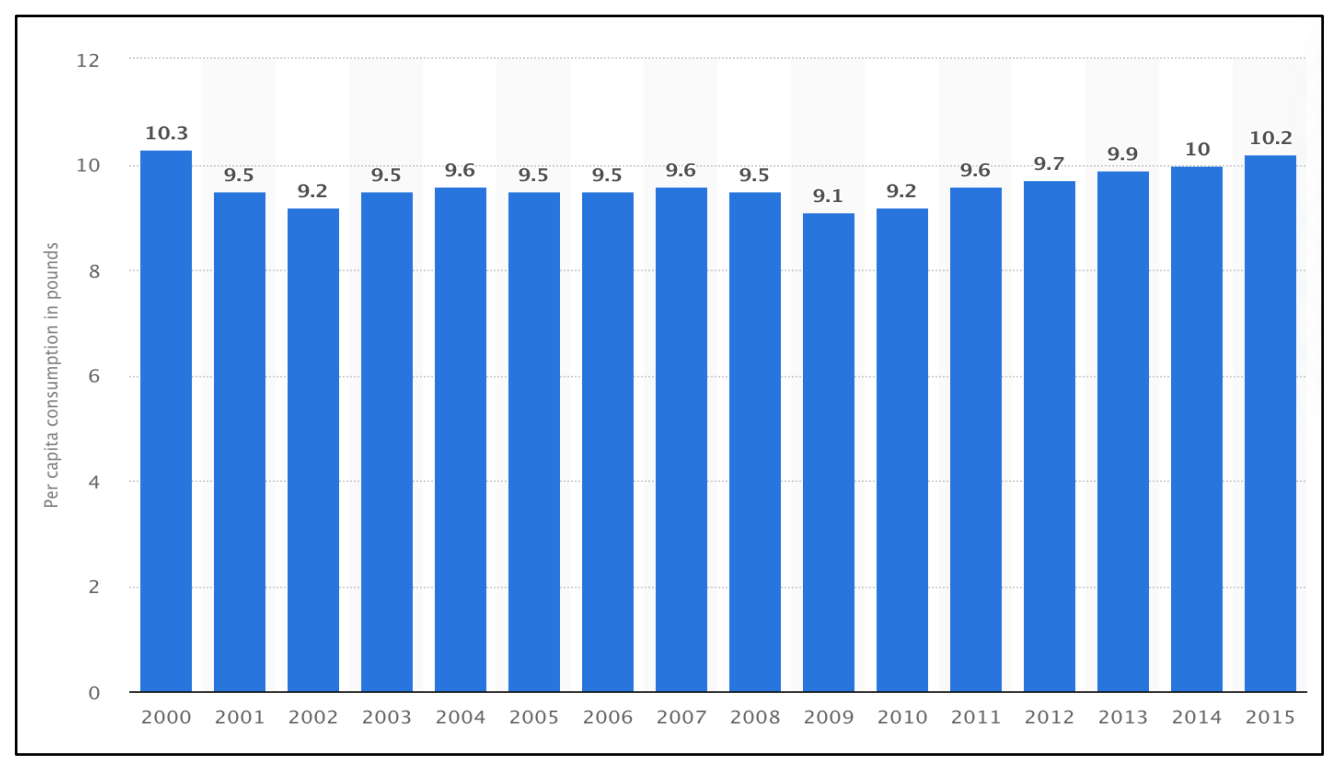

Bedford (2020) 
FIGURE 3

TOP TEN GREEN COFFEE PRODUCERS 2011

\begin{tabular}{|cc|}
\hline Country & Metric Tons Produced (millions) \\
\hline Brazil & 2.70 \\
Vietnam & 1.28 \\
Indonesia & 0.63 \\
Columbia & 0.47 \\
Ethiopia & 0.37 \\
Peru & 0.33 \\
India & 0.30 \\
Honduras & 0.28 \\
Mexico & 0.25 \\
Guatemala & 0.24 \\
\hline
\end{tabular}

Economics of Coffee (2020)

FIGURE 4

SPECIALTY COFFEE CONSUMPTION IN THE U.S.

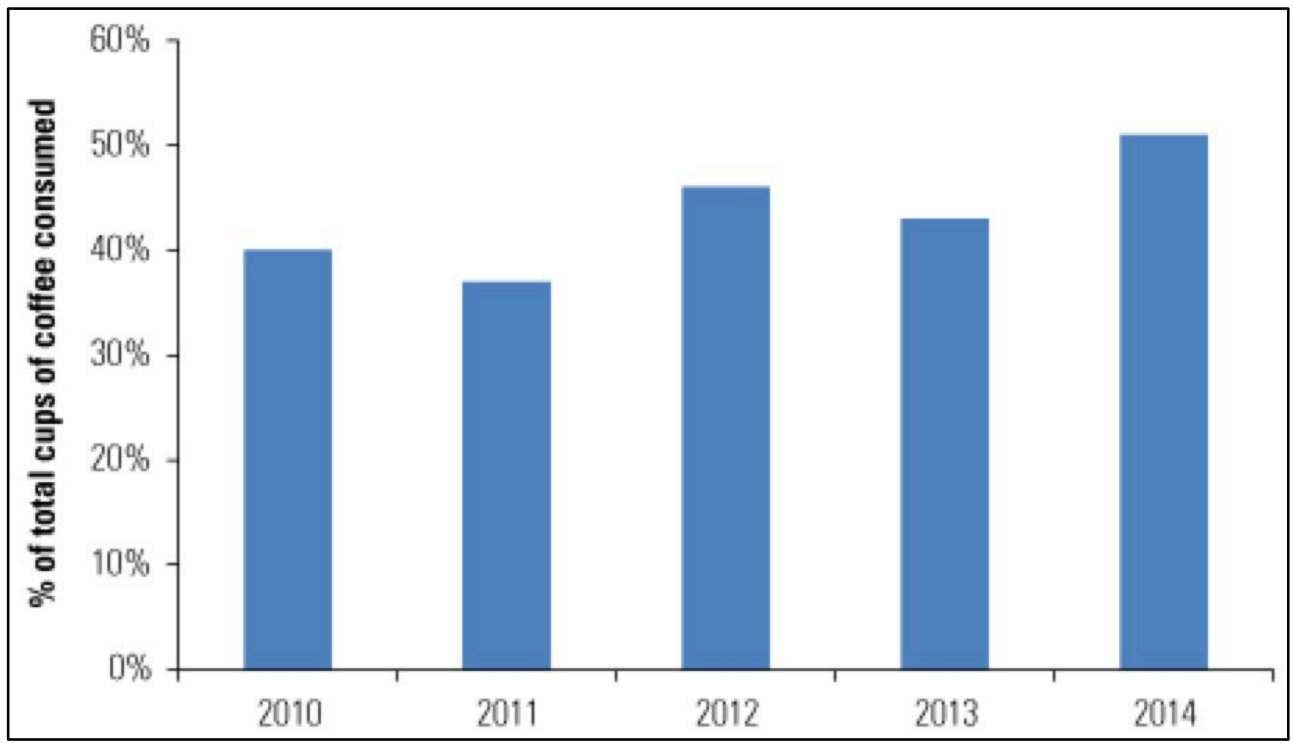

Brown Brothers Harriman (2015)

FIGURE 5

U.S. COFFEE VS. TEA CONSUMPTION BY AGE GROUP

\begin{tabular}{|ccc|}
\hline Age Group & \% Who Drink Coffee & \% Who Drink Tea \\
\hline $18-29$ & $42 \%$ & $42 \%$ \\
$30-44$ & $35 \%$ & $50 \%$ \\
$45-64$ & $28 \%$ & $62 \%$ \\
$65+$ & $21 \%$ & $70 \%$ \\
\hline
\end{tabular}

McCarthy (2015) 
FIGURE 6

THE COFFEE FAMILY TREE

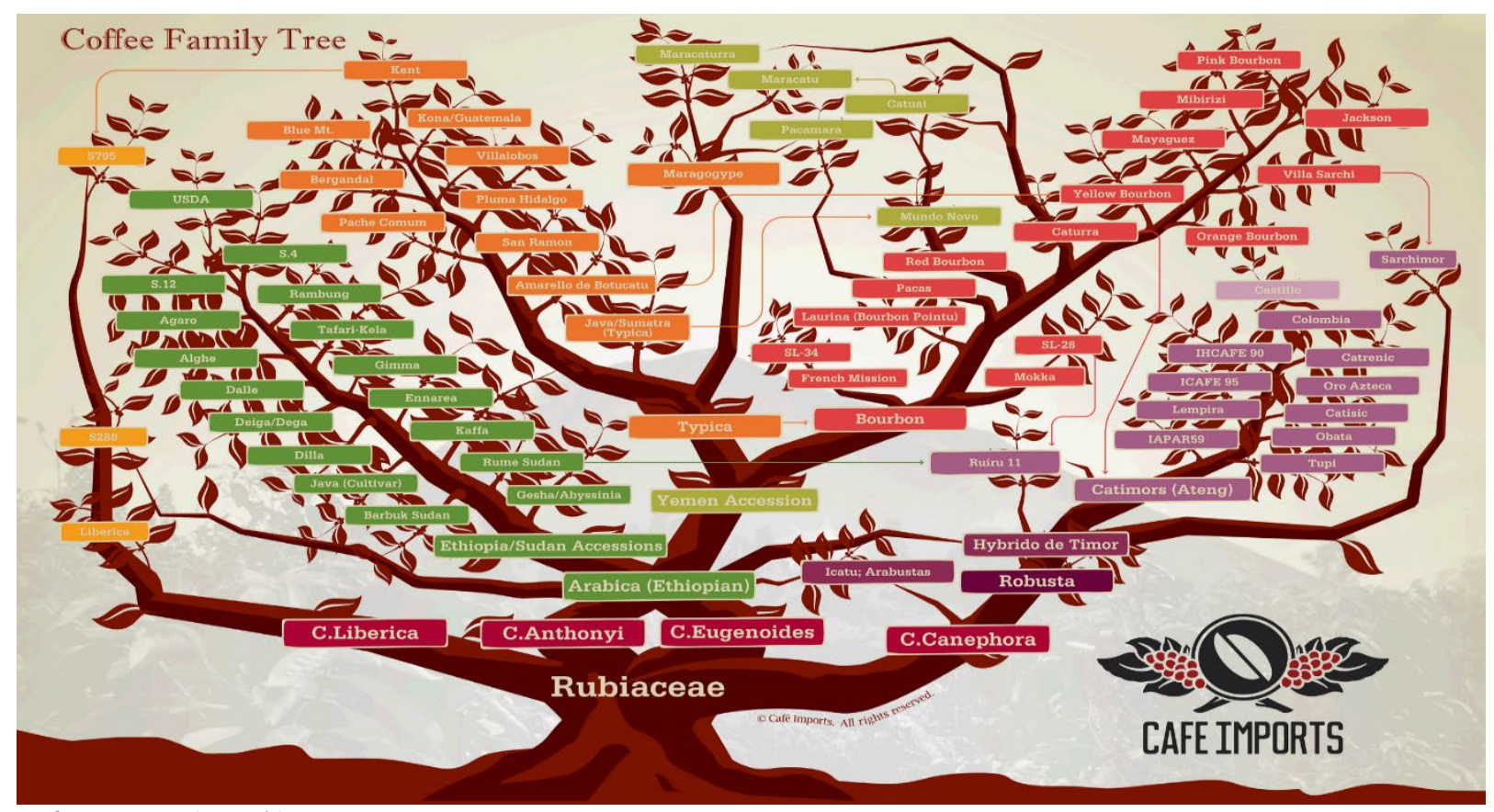

Café Imports (2016b)

FIGURE 7

THE MINNEAPOLIS COFFEE MILL

\section{The MPLS Coffee Mill Concept}

The MPLS Coffee Mill is a place where coffee professionals can come to refine their knowledge

and skills. It is an interactive, hands-on learning and coffee centered workspace.

The MPLS Coffee Mill will be staffed with some of the leading experts in al three disciplines of specialty coffee.

This space is outfitted with some of the latest and greatest coffee equipment for training and education, and we will be holding classes throughout the year in the space including our own educational content and $\mathrm{Q}$ certifications.

Our mission at The MPLS Coffee Mill is simple: to provide a supportive educational environment which nurtures innovation in the craft of specialty coffee.

This is a playground of sorts for friends of Cafe Imports and a space for some the best and brightest in specialty coffee to grow and develop.

\section{About the Programming:}

Our 3 day educational programming is broken down to...

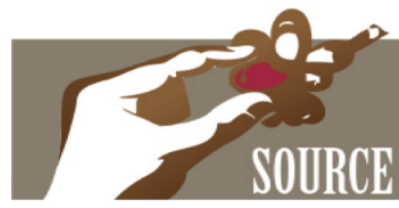

Day 1 - Source

Green Coffee Sourcing, Sample Roasting and Cupping/Analysis

Class Overview

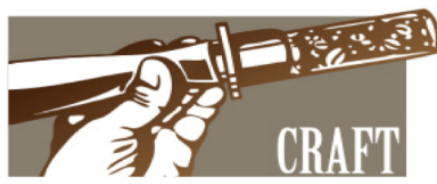

Day 2 - Craft

Production roasting skills and profile roasting education.

Class Overview

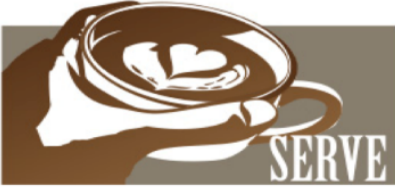

Day 3 - Serve

Barista training and behind the counter education.

Class Overview

Café Imports (2016c)

10 Journal of Applied Business and Economics Vol. 23(4) 2021 
FIGURE 8

SAMPLE ACES FARMER DETAIL

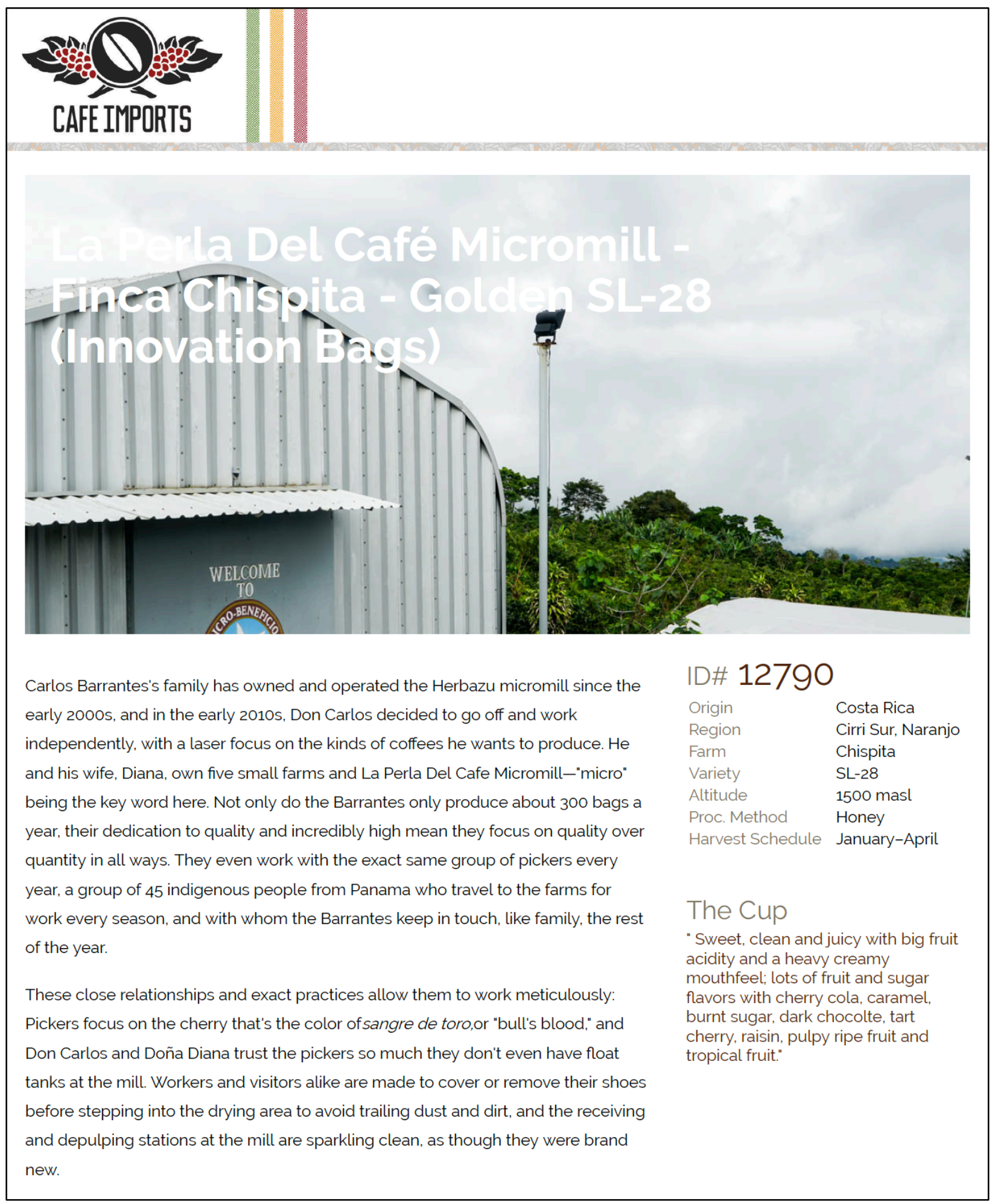

Café Imports (2019) 


\section{TEACHING NOTE}

\section{CASE PURPOSE}

The purpose of this case is to illustrate how an entrepreneurial company can innovate in a commodity industry and contribute to the common good through principled entrepreneurship. It is intended for undergraduate introductory-level or social entrepreneurship courses, with the analysis structured around Porter's Five Forces and an application of company principles to the business model canvas. Students are also left with two initiatives the company is currently considering, and some discussion can revolve around how these initiatives might contribute to the company's pursuit of its principles and brand. Key takeaways for students include 1) The importance of "living your values" as an entrepreneurial company, 2) That "doing good" is not at odds with achieving competitive advantage, and 3) Businesses models should be built around core principles rather than the other way around.

A secondary purpose of this case study is to illustrate an alternative path that students might take toward business ownership. Most undergraduate students will not have considered how working for an entrepreneurial company might lead to business ownership or even that this is a possibility. This case is an example of an alternative way of developing their careers to see business ownership opportunities at a relatively young age.

\section{CASE QUESTIONS}

1) From the information in the case, how would you describe Café Imports' main values? In what ways does Café Imports "live these values"? Fill out a business model canvas for Café Imports and include how the company's value system applies to each aspect of the canvas.

2) Using the Porter's Five Forces model, analyze the coffee importing industry. Which of the forces are strongest and what has Café Imports done to position itself strategically in response to these forces?

3) Putting your analysis from questions 1 and 2 together, summarize how Café Imports' value system has directly led to brand recognition and competitive advantage.

4) How might hiring Andy and/or implementing a "small bag" product line help Café Imports further pursue its values?

5) Discuss your thoughts on why Café Imports would offer Noah ownership. How might you put yourself on a similar path? What principles/values do you hope to incorporate into your own career?

\section{SUPPLEMENTAL RESOURCES}

Café Imports has developed a series of content that can be used as supplemental materials in this case. Below are links to select video blogs, informational reports, and educational tools.

\section{Video Blogs}

- https://www.cafeimports.com/europe/blog/2015/07/23/cesmach/

- https://www.cafeimports.com/europe/blog/shabbir/

\section{Brochures and Educational Tools}

- https://images.cafeimports.com/Cafe_Imports_Progress_Report_Community_2017.pdf

- http://images.cafeimports.com/Cafe_Imports_Progress_Report_Development_2017.pdf

- https://www.cafeimports.com/europe/education-cie 


\section{CLASSROOM STRATEGY}

\section{Introduction Discussion on the Common Good}

It is beneficial to the case analysis to begin with a roughly 30 -minute general discussion of the "common good" along with what responsibilities businesses have and to whom. The instructor can choose how to frame this discussion, but the three readings below are excellent resources for preparation.

- Naughton (2019)

- Naughton and Goodpastor (Forthcoming)

- Argandona (1998)

Based on these readings, a suggested framing of this topic is to break it down into three components:

1. Types of "Good" That a Business Produces

Naughton (2019) posits that if a business is to be meaningful and viewed with legitimacy, it must start by thinking "institutionally" (how it connects to other institutions in society): "If we are to think institutionally, we cannot compartmentalize the institution of business from our other institutions... We need to see the organic connection of business to the larger society, and, in particular, to other societal institutions."

Institutional thinking guides purpose, which "good leaders" define as the common good. Business purpose clarifies two aspects: "(1) which goods are to be pursued by an institution, and (2) how it orders such goods for the good of the whole."

The operationalization of business purpose should be evident in the three types of goods an institution produces:

- Good work: work is organized in a manner so that employees develop their gifts and talents for themselves as well as for the business and the larger community.

- Good goods: products and services are provided to the world that are needed and that create value.

- Good wealth: the business creates sustainable wealth and distributes wealth justly to all stakeholders.

2. Dignity of the Individual and "Authentic Human Development"

Naughton and Goodpaster (Forthcoming) state that producing Good Work, Good Goods, and Good Wealth does not entirely encapsulate common good: it must also include the establishment of relationships that lead to the "integral" or "authentic" development of each party involved. This idea stems from Catholic social teaching in its emphasis on human dignity and solidarity with those who are vulnerable and/or disadvantaged, and promotes the good of the whole person and of all persons: "Integral human development offers a window on the common good that is distinctive, in that it eschews the vocabulary of maximizing interests, for it insists on the dignity of each person and the dignity of the human community without compromise or trade-off."

3. Alignment of Individual Good and Common Good

The third element of this framing is the non-mutually-exclusive relationship between individual and common good, as described by Argadona (1998). Argadona states that people have goals that transcend those of society (goals of self-interest, like wealth or recognition or the solving of a personal problem), but that advancing the common good is often key to achieving those goals (and vice-versa). For instance, personal health is impacted by the overall health of society (and vice-versa), just as personal economics are impacted by the economic state of society (and vice-versa). Naughton and Goodpastor (Forthcoming) refer to this relationship as the sharing of participative goods: if a candle's purpose is to light a room, it benefits from more candles being lit, and "when a candle lights another candle, it loses nothing." 


\section{Discussion of Common Good}

The discussion can begin with asking students to spend five minutes in groups defining "common good" and what responsibility a business has (if any) to serve the common good. As part of their discussion, students might also be asked to react to Milton Friedman's famous statement that "the social responsibility of business is to increase profits" (Friedman, 1970). The instructor can then ask groups to share their responses and use deeper questions to tease out the above framing on the whiteboard (types of good, authentic human development, alignment of individual good and common good). If definitions of common good are relatively generic, the instructor should probe the students to think more deeply, with questions like "What does a business produce that accomplishes that?" or "To whom does it have that responsibility?" Since the purpose of this discussion is to help students clarify their notion of common good, it is highly encouraged that the instructor challenges students to articulate why they believe what they believe about the common good and corporate responsibility. The instructor should also challenge students to provide examples of the alignment of individual and common good.

\section{Application to Café Imports}

To transition the discussion of common good to Café Imports, it is useful to show one or two of the videos in the Supplemental Resources above to help students visualize who coffee farmers are and what Café Imports is doing to impact their lives. The instructor can then ask students to discuss this one element of Café Imports (its relationship with coffee growers) based on the framing above (types of good, relationships, alignment of individual and common good). Chances are, some of this will have already come up, but this is a good opportunity to have students spell out how different aspects of the business contribute to dignity, development, wealth, etc. for coffee growers (education initiatives, competitions, coffee sendback program, etc.).

\section{Question 1}

Following the introduction discussion, the instructor can switch the context of the conversation to that of "principled" or "value-driven" entrepreneurship in relation to pursuit of the common good and business development. It is helpful to show the company mission and values page on its website and refer to how Andrew spoke about the business when interviewing Noah. A key point here is that there are no "right" values or purpose for a business; it is only important that they are authentic, that they are consistent with the common good, and they are used to guide all company decisions.

Students should then be asked to build out the main components of the business model canvas with regard to company mission and values and share their work with the class for discussion (see Exhibit TN1). Some of the activities and relationships will likely have come up already, so students may be able to move through this fairly quickly. The key part of this discussion is around how these values materialize in everything the company does - this is an illustration of how a company builds its business model around its core values rather than the other way around. In other words, it is an opportunity to emphasize how Café Imports is living its values via importing and distributing green coffee beans.

It is not important that you stick to only the values as noted in Exhibit TN-1 or even that you put them in the same place on the business model canvas (you may opt to put the values directly in the boxes where they apply).

\section{Questions 2 and 3}

The next step is to make the connection to how the company's values have allowed it to innovate in a commodity industry. You could almost make the argument that what Café Imports is doing is attempting to "lead a movement" rather than buy and sell coffee. There are several strategies for making this connection, but an effective one is by using the Porter's Five Forces Model (see Exhibit TN-2).

There are a few significant aspects to emphasize in this analysis. First, by making the farmer important (through helping farmers grow higher-quality beans, by connecting roasters to farmers through country-oforigin visits and the Coffee Send-Back Program, by publicizing the stories of farmers, etc.), Café Imports 
is combating the high internal rivalry in coffee bean importing as well as the threat of new entrants because it takes time and money to pursue this strategy.

Second, by educating baristas and micro-roasters and making specialty coffees more available to them, they are addressing the power of buyers in the industry (since there are many sellers of coffee beans and it is a difficult product to differentiate). Additionally, the emphasis on "doing business better" provides an additional reason to buy from Café Imports. This also fits with what we know about millennials, that they want to buy from companies who share their values (Buck, 2017). Since millennials are an important group of coffee consumers, a case can be made that this strategy fits a megatrend in consumer buying.

Third, some students might argue that Café Imports' strategies around empowering farmers actually increases the power of suppliers. This is true, and counterintuitive to what Porter's model might prescribe as strategy. However, it is also an important factor in differentiation and we might expect that these strategies will lead to farmer loyalty to Café Imports. This is a good opportunity to tie this back to the notion of "participative goods" and emphasize that "win-win" approaches to strategy are often better than "winnertake-all" approaches.

\section{Question 4}

This question is intended to get students to frame these decisions in terms of company values. For instance, having a dedicated creative director might allow Café Imports to capture stories of more farmers and to better spread the word about the impact the company is having on the lives of coffee farmers, on sustainability, in empowering women, etc., which fit with company values around improving lives and spreading knowledge. Likewise, it could be argued that the "small bag" product line might enable microroasters to experiment and learn, which would be good for the craft coffee industry, which would in turn be good for farmers, and this fits with values around quality and improving lives.

\section{Question 5}

This question is optional, but is intended to get students thinking about their own career path and how they might put themselves in a position to create value for a growing entrepreneurial firm. Most will not have considered that working for a small firm might be a route to business ownership, and this case introduces them to this concept. This question can also be used to help students think about how they might find an occupation that fits with their own core values.

\section{EPILOGUE}

In the following year, Noah and the founders of Café Imports completed the deal that made Noah a shareholder of the company. Noah remarked about how overwhelming the legal part of the process had been and that "someone should teach a semester-long class on it." Nonetheless, he was excited to be an owner.

The company continued to invest in its country of origin programs to build relationships with farmers who produced premium coffee beans. As of 2018, the Women Coffee Producers Program had expanded to include nine coffee cooperatives in Columbia, Guatemala, Mexico, Honduras, and Indonesia, and Café Imports was actively looking to partner with additional cooperatives in other countries of origin. In 2017 and 2018, Café Imports donated approximately $\$ 120,000$ in premiums to its partners in this program. The company also began Best Cup Competitions in Brazil and El Salvador (while continuing competitions in Columbia), and as of 2018 had injected over $\$ 2,000,000$ in quality premiums to small rural coffee farmers in these three countries. Additionally, the Coffee Send-Back program became much more popular, and in May of 2017 Café Imports delivered over 125 pounds of coffee from 46 roasters to its farmer and micromill partners in Costa Rica.

As for the two initiatives Noah had been contemplating, he decided to move forward both with hiring his friend Andy and implementing the new "small bag" coffee strategy. Andy traveled to countries of origin to spearhead the effort to capture the stories of farmers (and how Café Imports was helping them innovate) through pictures and video, which he then shared via social media and the Café Imports blog. He also gave 
Café Imports a more consistent look, with color schemes, fonts, and messaging, the value of which Noah had underestimated before it was done. Most important, having Andy full time gave Café Imports a resource for experimenting with creative content, some of which resulted in very positive national attention.

The "small bags" were sold under the brand La Bodega with the tagline "Bags you can carry." These 50-pound lots quickly became popular with roasters as a means to try additional varieties of coffee, and in many instances roasters began opting to purchase three 50-pound bags as opposed to one 150-pound bag, which had a positive impact on Café Imports' margins.

\section{TEACHING NOTE 1 BUSINESS MODEL CANVAS WITH COMPANY VALUES}

\begin{tabular}{|c|c|c|c|c|c|}
\hline \multicolumn{6}{|c|}{$\begin{array}{l}\text { Company Values/Principles } \\
\text { Increase the quality of life for those involved, from the tree to the cup, through the commerce of } \\
\text { coffee. } \\
\text { Decrease our negative impact on the earth through responsible and proactive business practices. } \\
\text { Share our passion for great coffee through education and example. }\end{array}$} \\
\hline $\begin{array}{l}\text { Key Partners } \\
\text { Coffee Farmers, } \\
\text { Associations \& } \\
\text { Cooperatives, } \\
\text { Export Groups }\end{array}$ & $\begin{array}{l}\text { Key Activities } \\
\text { Women Coffee } \\
\text { Producers } \\
\text { Program, Best Cup } \\
\text { Competitions, } \\
\text { Coffee Send Back } \\
\text { Program, } \\
\text { Capturing \& } \\
\text { Promoting } \\
\text { Farmers as } \\
\text { Individuals } \\
\\
\text { Key Resources } \\
\text { Employees = } \\
\text { Experts (baristas, } \\
\text { roasters, } \\
\text { agronomy, etc.), } \\
\text { R\&D (cupping } \\
\text { recipes), Quarterly } \\
\text { hotwash event }\end{array}$ & \multicolumn{2}{|c|}{$\begin{array}{l}\text { Value } \\
\text { Propositions } \\
\text { High-Quality } \\
\text { Coffee; } \\
\text { connection } \\
\text { between roasters } \\
\text { and farmers }\end{array}$} & $\begin{array}{l}\text { Customer } \\
\text { Relationships } \\
\text { Barista } \\
\text { Competitions } \\
\text { (opportunity to } \\
\text { travel to countries } \\
\text { of origin), } \\
\text { Minneapolis } \\
\text { Coffee Mill, } \\
\text { Marketing Material } \\
\text { (Variety Tree, } \\
\text { Farmers' Stories) } \\
\text { Channels } \\
\text { Target baristas } \\
\text { with high-quality } \\
\text { coffees and } \\
\text { baristas tend to } \\
\text { then order Café } \\
\text { Imports' mid-tier } \\
\text { coffees }\end{array}$ & $\begin{array}{l}\text { Customer } \\
\text { Segments } \\
\text { Large and mid- } \\
\text { sized roasters, } \\
\text { Micro roasters, } \\
\text { Coffee shop } \\
\text { roasters }\end{array}$ \\
\hline \multicolumn{3}{|c|}{$\begin{array}{l}\text { Cost premiums for high-quality coffee, investment } \\
\text { in training for employees and farmers, investment in } \\
\text { empowerment programs for farmers, investment in } \\
\text { marketing/branding. }\end{array}$} & \multicolumn{3}{|c|}{$\begin{array}{l}\text { Premium prices for higher-quality coffee, sales } \\
\text { of higher-quality beans leads to sales of higher- } \\
\text { volume beans. }\end{array}$} \\
\hline
\end{tabular}


TEACHING NOTE 2

PORTER'S FIVE FORCES MODEL

\section{Threat of Entry}

Attributes:

- Few barriers

- No dominant brand

- Little technical knowledge required

- Low $\$$ required (to buy a container of coffee)

Threat $=$ High

- Café Imports Strategy = Establish long-term relationships with high-quality suppliers that take time and money to replicate.

\section{Internal Rivalry}

Attributes:

- Consumption flat

- Little differentiation

- Market dominated by a few large players

Power $=$ High

- Café Imports Strategy $=$ Change the perception that coffee beans are a commodity; Educate and build relationships so that it matters where/who the beans come from.

\section{Threat of Substitutes}

Attributes:

- Growing demand for energy drinks

- Younger generation drinking as much tea as coffee

Threat $=$ High

- Café Imports Strategy = Promote movement toward specialty coffee, especially via education of baristas and micro-roasters (could make comparison to microbrew industry - growing demand from consumers as more craft brewers emerge).

\begin{tabular}{|l|}
\hline \multicolumn{1}{|c|}{ Power of Buyers } \\
Attributes: \\
$\bullet \quad$ Large roasters can buy in bulk \\
Small roasters have options for supply \\
Power = Medium \\
Café Imports Strategy = Provide small \\
roasters the "story"; allows them to \\
communicate quality to their customers and \\
gives them a reason to buy not just high-end \\
coffees from Café Imports, but bulk coffees \\
too.
\end{tabular}

\section{Power of Suppliers}

Attributes:

- Many options for farmers to sell to importers

- $\quad$ But these are generally small farms and it is difficult for farmers to differentiate product

Power $=$ Low

- Café Imports Strategy = Incent farmers to grow better coffee and pay them more for it.

- But... this gives farmers more power!! 


\section{REFERENCES}

Argandona, A. (1998). The Stakeholder Theory and the Common Good. Journal of Business Ethics, 17, $1093-1102$.

Bedford, E. (2020). U.S. per Capita Consumption of Coffee 2000-2015. Retrieved July 31, 2020, from https://www.statista.com/statistics/184212/per-capita-consumption-of-coffee-in-the-us-since2000/

Brown Brothers Harriman. (2015). The Continued Rise of Premium Coffee in the U.S.: Will it DeCommoditize Coffee? Retrieved May 20, 2016, from https://www.bbh.com/en-us/insights/thecontinued-rise-of-premium-coffee-in-the-u-s---will-it-de-commoditize-coffee--10966

Buck, S. (2017). As Millennials Demand More Meaning, Older Brands Are Not Aging Well. Retrieved July 3, 2018, from https://www.fastcompany.com/40477211/as-millennials-demand-moremeaning-older-brands-are-not-aging-well

Café Imports. (2016a). Mission. Retrieved May 20, 2016, from https://www.cafeimports.com/northamerica/mission/

Café Imports. (2016b). The Coffee Family Tree. Retrieved May 20, 2016, from https://www.cafeimports.com/north-america/blog/coffee-family-tree/

Café Imports. (2016c). Café Imports Education. Retrieved May 20, 2016, from https://www.cafeimports.com/north-america/education

Café Imports. (2018). Steps Toward Gender Equity: A Bit About Our Women Coffee Producers Program. Retrieved August 31, 2018, from https://www.cafeimports.com/northamerica/blog/2018/07/18/steps-toward-gender-equity-a-bit-about-our-women-coffee-producersprogram/

Café Imports. (2019). Microlots: Best in Show. Retrieved September 3, 2019, from https://www.cafeimports.com/north-america/microlots

Economics of Coffee. (n.d.). Retrieved July 31, 2020, from https://en.wikipedia.org/wiki/Economics_of_coffee

Fernau, K. (2013). Coffee is a $\$ 30$ billion-a-year $\bar{U} . \bar{S}$. industry - and it's growing. Retrieved May 20, 2016, from http://archive.azcentral.com/business/consumer/articles/20130410coffee-is-abillionayear-us-industry-and-its-growing.html

Friedman, M. (1970, September 13). The social responsibility of business is to increase profits. New York Times Magazine.

IBIS World. (2016). Industry Report: Coffee Production.

McCarthy, N. (2015). Younger Americans are Ditching Coffee for Tea. Retrieved May 18, 2020, from https://www.forbes.com/sites/niallmccarthy/2015/02/26/younger-americans-are-ditching-coffeefor-tea-infographic/\#364a8e983595

Mello, J. (2012). Brazilian Coffee Industry. Retrieved May 17, 2016, from https://thebrazilbusiness.com/article/brazilian-coffee-industry

Naughton, M. (2019). Getting Work Right: Labor and Leisure in a Fragmented World. Emmaus Road.

Naughton, M., \& Goodpastor, K. (Forthcoming). The Institutional Insight Underlying Shareholder/ Stakeholder Approaches to Business Ethics.

Specialty Coffee Association of America. (2016). U.S. Specialty Coffee Facts and Figures. Retrieved May 17, 2016, from http://www.scaa.org/?page=resources\&d=facts-and-figures 